\title{
Privatization Chinese Style: Tuition Reforms in China's Postsecondary Education
}

Lanlin Zhang (The University of Western Ontario)

\begin{abstract}
Since the endorsement of a socialist market economy in 1992 in the $14^{\text {th }}$ National Congress of the Chinese Communist Party, self-financing and fee-charging principles have been widely adopted, and finally legitimized in China's higher education system. However, reforms in China's post secondary education, mainly privatization and tuition fee hikes, have produced some serious controversies and concerns among students, parents, and international education researchers. This article delves into the issues of postsecondary education reform in China and brings into attention problems that occur when policies are institutionalized in a centralized decentralization setting.
\end{abstract}

Résumé: Depuis l'adhésion à une économie de marché socialiste au 14è Congrès national du Parti communiste chinois, les principes d'autofinance et de privatisation ont été adoptés partout, et finalement légitimé dans le système d'éducation tertiaire en Chine. Néanmoins, les réformes dans le système d'étude post-secondaire chinois, surtout dans la privatisation et dans la hausse des frais de scolarité, ont provoqué de sérieuses controverses et des soucis chez les étudiants, parents, et chercheurs internationaux sur l'enseignement. Cet article étudie les problèmes de réforme au niveau post-secondaire en Chine et attire l'attention sur les problèmes qui surviennent lorsque les politiques se font institutionnalisées dans un milieu de décentralisation centralisée.

\section{Introduction}

After the endorsement of a socialist market economy in 1992 in the $14^{\text {th }}$ National Congress of the Chinese Communist Party, self-financing and feecharging principles were widely adopted, and finally legitimized in China's higher education system. From 1997 onwards, all students enrolled in post secondary education in China have to pay tuition fees. This is one of the most significant moves of China's education privatization reform. Along with the development of private (minban) universities and independent colleges affiliated with prestigious universities, the Chinese higher education system is taking giant leaps forward towards privatization, with Chinese characteristics.

It is said that throughout the world, there is a clear trend for universities to diversify their sources of income and become less dependent on government funding (Johnstone, 2004). It seems most universities in the world are increasing their tuition fees (Innychyj, 2003). As a result, in many countries higher education has effectively been privatized. However, privatization has also been one of the heated debates over the last years. For some, it simply means 
increasing the roles of parents in education financing. This neo-liberal movement has thus rather negative and threatening connotations: it is associated with increased inequalities in access to education and the breaking of social cohesion. For others, privatization is deemed a much more positive move, implying more resources for the education sector, more efficient use of these resources, and more flexibility in education delivery (Caillods, 2002).

An influential theory behind the privatization tide is a theory called Cost Sharing which refers to a shift of the higher educational cost burden from exclusive or near exclusive reliance on government, or taxpayers, to some financial reliance upon parents and/or students, either in the form of tuition fees or of "user charges" to cover the costs of formerly governmentally- or institutionally- provided room and board (Johnstone, 2004). The theory assumes that the costs of higher education in all countries and in all situations can be viewed as emanating from four principal parties: (1) the government, or taxpayers; (2) parents; (3) students; and/or (4) individual or institutional donors (p 2). Higher education is perceived to be a corporate business. Hence, students are the stakeholders of higher education and should share the cost. Johnstone has been invited to China several times and his theory is quite popular amongst many Chinese education researchers and educational administrators.

According to Mr. Zhou Ji, China's current Minister of Education, in 1998, 1.08 million students were able to receive higher education ( 9.8 per cent of high school graduates), but in 2003, 4.2 million students were able to receive post secondary education (with the admission rate of 17 per cent) and nearly 20 million young people are in Chinese higher education institutions, giving it the world's largest share of students in higher education. (Xinhua News Agency, 2004).

Nonetheless, also amongst this soaring increase of student enrollment is the dramatic increase of tuition fees and other miscellaneous fees which have exerted a financial burden upon the majority of Chinese families. In a span of nearly four decades from 1952 to the early 1990 s, most Chinese college students received free higher education because of huge government subsidies to universities. In return, the students were willing to take whatever jobs they were assigned by the government upon graduation. However, in the early $1990 \mathrm{~s}$, this system was deemed "incompatible with the growth of a market economy", and Chinese colleges and universities began charging tuition fees.

This article reviews postsecondary education reforms in China, mainly privatization and the tuition fee hike. It will first review briefly the theoretical framework of privatization, and especially the Cost Sharing Theory, which have greatly influenced China's education reform in recent years. Focus will then be placed on the vertical and horizontal introduction of privatization in China's history and at present. A further introduction of the controversial issue of tuition fee increase and privatization in the People's Republic of China will be presented after that. The article will conclude with some suggestions regarding privatization and especially the tuition fee reform in China's post secondary education for educational researchers and policy makers. 


\section{Educational Privatization}

The term privatization is used as an umbrella to refer to many different educational programs and policies. Levin (2001) defines it as "the transfer of activities, assets, and responsibilities from government/public institutions and organizations to private individuals and agencies". Also privatization is often thought of as "liberalization"-where agents are freed from government regulations, or as "marketization" where new markets are created as alternatives to government services or state allocation systems. Belfield \& Levin (2002) note that education can be undertaken by either (a) increasing the number and proportion of private providers; (b) raising the amount of funds contributed directly by the users of the services (i.e., students and their families) and lower the amount contributed through subsidies; or (c) enhancing parental monitoring of schools and school choice over government rules and regulations. The evaluative criteria include (1) freedom of choice, (2) efficiency, (3) equity, and (4) social cohesion.

Privatization is closely associated with the theory of Cost Sharing by Johnstone (1986, 1991, 1992, 2002, 2003, cited in Johnstone 2004). Cost Sharing refers to a shift of the higher educational cost burden from exclusive or near exclusive reliance on government, or taxpayers, to some financial reliance upon parents and/or students, either in the form of tuition fees or of "user charges" to cover the costs of formerly governmentally- or institutionallyprovided room and board (Johnstone 2004, p.1). He argues that higher education at the beginning of the $21^{\text {st }}$ century is in ever-greater demand, both from individual students and their families, for the occupational and social status it is presumed to convey, and from governments, for the public benefits it is presumed to bring to the social, cultural, and economic wellbeing of countries. However, higher education is also costly, especially when its high unit, or perstudent, costs are magnified by dramatically increased enrollment pressures. Governments are also besieged with other pressing public needs, many of which seem more politically compelling than the claims of higher education and which, together with higher demand, greatly exceed, in almost all countries, the available scarce public revenues.

Johnstone lists seven forms of Cost Sharing: (1) the beginning of tuition (where higher education was formerly free). (2) the addition of a special tuitionpaying track while maintaining free higher education for the regularly admitted, state supported students. (3) the very sharp rise in tuition (where public sector tuition already exists). (4) the imposition of "user charges," or fees to recover the expenses of institutionally provided and formerly heavily subsidized residence and dining halls. (5) the diminution of student grants or scholarships. (6) an increase in the effective cost recovery on student loans, and (7) the limitation of capacity in the low or tuition free public sector together with the official encouragement (and frequently a public subsidization) of a tuitiondependent private higher education sector. 
One of the rationales behind the Cost Sharing Theory is that cost sharing is viewed as a step in the direction of greater efficiency, responsiveness, and equity, whereas where students and their families are paying little or nothing, the students may be too tempted to remain in that status for a very long time, denying the society and the economy the advantage of their potential productivity and presumed enhanced usefulness, whether to themselves or to the state (Johnstone, 2004).

Johnstone argues that in recent years, throughout the world the role of government is changing, partly as a consequence of the ending of the cold war, but also because of economic liberalization and new information technology. Worldwide, there is a clear trend for universities to diversify their sources of income and become less dependent on government funding. In many countries higher education has effectively been privatized. Many universities are increasingly charging their clients directly for the services they provide, usually in the form of tuition fees which in many countries have often been increasing in excess of inflation rates. This makes the running of universities more like a corporate business. In both developed and developing countries, families and individuals have to commit higher and higher proportions of their income to the purchase of educational products for their children. As a country with a long tradition of valuing education, China's parents will go any distance to enable their children's realization of a higher education dream.

\section{China's Private Education: History And Present Situation}

Education in China has long been a system through which people climb the social ladder, especially into the ruling class. In both traditional and modern China, the education system has had an even lower autonomy from the political and economic systems than in the west, making a study of the context of vital importance (Hayhoe, 1984, p.29). This section will review the private education system from a historical perspective and then have a look at the current situation in China's higher education system.

Private education had existed in China through the centuries ever since the days of the Spring and Autumn periods (770-475 BC), and flourished in the Han Dynasty (206 BC-220 AD). During the Tang Dynasty (619-907 AD), while higher educational institutions were maintained mainly by the government, private academies of learning (shuyuan) had started to grow, and persisted all the way through to the late Qing Dynasty (1636-1911 AD) (Ding \& Liu, 1992; Yang \& Peng, 1992). It is estimated that there were about twelve hundred such academies in the Ming Dynasty, and the number had risen to over nineteen hundred academies by the Qing period (Chen et al., 1981, pp 86-87).

Since the Opium Wars of the mid 1800 s, private missionary schools and universities gradually sprang up all over China. By 1917,80 per cent of the total university student population were from missionary universities (China National Institute of Education Research, 1995, p.4). Even in 1950, shortly after the founding of the People's Republic of China, 39 percent of the total of 227 universities were private ones, admitting over 40 per cent of the high school 
graduates (Min, 1994). However, by 1956 all private institutions of higher education were transformed into public ones after the reorganization of universities and departments under the influence of the Soviet Union. With this, the long history of private higher education in China closed its first chapter and students were accorded free higher education until the 1980s.

The second chapter of the development in private higher education in China started in the early 1980s when China officially launched its economic reform and Open Door Policy. The economic modernization not only fostered the growth of a market economy but has also caused a structural change in higher education. Reshuffling the monopolistic role of the state in educational provision, reform in educational structure started in the mid-1980s has manifested a mix of private and public consumption (Cheng, 1995; Hayhoe, 1996; Mok, 1996). There were more than 800 private higher educational institutions across China in 1994. This number has been steadily growing ever since to 1230 in 1996, 1252 in 1997, and 1277 in 1999, among which 37 are fully recognized by the Ministry of Education (MOE), with authority to grant their own graduation diplomas; whilst the others can only issue students with certificates (Hu, 1999; Mok, 2000; Yang, 2000). In 2003, there were approximately 1200 minban (private) institutions in China operating at the tertiary level, enrolling 1.5 million students or $39 \%$ of all college and university students in China. Only 133 institutions, however, can grant bachelor's or associate degrees; the rest offer certificates, self-study courses, or other forms of education and training (Mohrman, 2003). Mok (1996) has divided the development of China's private higher education after Mao Zedong into three periods: (1) the rise of private higher education, 1982-1986; (2) the rectification of private higher education 1987-1991; and (3) development of private higher education (1992-present). Yan \& Lin (2004) divide this phase of private education resurgence into another three periods: (1) Recovery and development (1978-1992); (2) Fast development (1992-1997); and (3) Normalization (1997present). Each period was earmarked by the introduction and implementation of new laws and regulations permitting or encouraging development of private economic and educational enterprises.

It is noteworthy that in today's China, the word private (sili) does not appear frequently in names of higher education institutions, perhaps for the ideological connotations the word entails (after all the Chinese government still claims to be pursuing the socialist system, which is associated with public ownership). Many use the term minban (people-run). Very often people use the terms private and minban interchangeably. People working in private institutions, however, tend to label their institution as Minban instead of private. Currently, there are various names adopted in the private education sector. The following are terms and explanations used most frequently in private higher education in China.

1. Private (sili or minban) institutions are in control over budget and spending. Minban institutions can be privately or collectively 
owned. They can also be partly owned by the government, but administered by independent parties.

2. Minban Gongzhu (publicly owned but privately administered) institutions are owned and supported by the government through property and infrastructure.

3. Gongban Minzhu (publicly administered but privately supported) institutions are privately and/or state-funded, and further supported by the government through faculty, administration, and infrastructure.

These institutions are basically private institutions although some still retain quasi- or unofficial links to public universities, out of pragmatic considerations.

The privatization of contemporary Chinese post secondary education takes more forms than just the resurgence and development of private universities. Public universities also take initiatives to diversify the funding sources and enlarge their enrollments. The introduction of independent colleges, the creation of a Board of Governors, and of course the increase of tuition fees are some of the noteworthy strategies that universities adopt to survive and thrive.

Independent colleges (The full name is independent secondary colleges affiliated to general higher learning institutes, formerly known as state-owned and people-run secondary colleges) is a very special system that took its name only in 2003. It is considered to be the standardized way of the state-owned and people-run secondary college (Shi et al. 2004). It has independent status of a legal persona, independent campus, and independent in granting academic credentials and accounting, but it is still closely allied with the university it is affiliated to. Its faculty members are usually from the mother university, and it takes advantage especially of the reputation that the public university has long established. In a sense it is a hybrid that is meant to produce more income for the mother university.

The emergence of a large number of independent colleges contributes significantly to the enlargement of the general higher education scale when the gross enrollment jumped from 9.8 per cent in 1998 to 17 per cent in 2003 . There are more than 300 state-owned and people-run secondary colleges which take up the responsibility of nurturing 30 per cent of the bachelor students by July 2003 . Meanwhile these colleges are renamed independent colleges and operate according to the standards stipulated in "Some Opinions Concerning Managing Colleges Affiliated to General Universities as a Pilot Project of New Mechanism and Mode" (abbr. "Opinions") by the Ministry of Education, abbreviated as the MOE (2003).

The issuance of the Opinions by the MOE is meant to regulate the existing independent colleges. It stipulates that public universities, as the selected applicants to run the independent colleges on an experimental level, can rely on their advantages in human resources and intangible assets to attract investment from enterprises, public sectors, associations as well as individuals to set up a new independent higher education organization, and is independent in granting academic credentials and accounting. Its operation follows the mechanism in 
Minban institutes. Independent colleges have the advantages of combining the brand name of state-owned universities and social resources including money, therefore they are taken as "an experimental special zone" in the system reform of China's higher education (Shi et al. 2004).

The MOE has confirmed 208 independent colleges by May 2004, 26 among which are those affiliated to the universities directly under the MOE and operate as an experiment. Independent colleges are densely located in Jiangsu and Zhejiang, two of the richest coastal provinces in China, and sparsely spread across the inner land and the west, due to the unbalanced development of private economy and the local residents' affordability in these areas.

Another symbol of privatization in China's higher education is that today Chinese public universities are required by the MOE to establish the Board of Governors system. The governors are honorary positions granted to those who have significantly contributed financially to the universities. In some provinces, it is the provincial finance ministers and in some provinces it is the persons who have donated the most to the university. For example one of the most prestigious universities, Wuhan University, has just approved a university regulation stating that individuals with a donation over 1 million Yuan or corporations with a donation over 2 million Yuan may serve on the Board of Governors for one term. Individuals with a donation over 3 million Yuan or corporations with a donation over 5 million Yuan may serve as Vice Governor General of the Board of Governors. An Honorary Professorship can be granted to individuals with a donation over 10 million Yuan. An Honorary Doctorate can be granted to individuals with a donation over 50 million Yuan (Wuhan University, 2003).

The most salient and perhaps easiest way to privatize higher education in China is to raise the tuition fees. Prior to the 1980 s all students admitted to institutions of higher learning had access to free tuition and accommodation, and were also free of other fees. During the period of the planned economy (19491979), this "practice guaranteed the supply of qualified personnel" needed by the country (Ling, 1993, p. 18). In 1989, universities began to charge miscellaneous fees (Xuezafei) on the entire student population, for the first time since 1949 when the People's Republic was founded.

By 1993, these miscellaneous fees ranged from 200 Yuan to 400 Yuan. In 1995 the State Education Commission (previous name for the MOE) decided to implement tuition reform on a larger scale and to gradually abolish the free tuition system by the year 2000 . Universities quickly jumped to welcome this decision, and by September 1995, over 200 universities and colleges charged tuition of 1000 to 2000 Yuan and additional miscellaneous fees on all students. "According to the Commission, most colleges and universities will introduce the new system by 1997 , with all having done so by the year 2000 " (Zhou, 1995, p. 15). The real situation was that by the fall semester 1997, all Chinese universities began charging tuition fees. The bureaucratic system has never been so efficient before. The fees soon soared in all universities in China, with ratifications from the MOE. In 2003 most universities charge their students 
around 6000 Yuan (See Table 1 for an example for the tuition fees charged by some key universities in China).

Table 1. Tuition fees for some key Chinese universities (Source: Xinhua News Agency, August 15, 2004)

\begin{tabular}{|l|l|}
\hline Name of university & Tuition fee (Yuan RMB) \\
\hline Qinghua University & 5000 \\
\hline Beijing University & $4900-5300$ for most, 6000 for Medical \\
\hline Beijing Teacher's University & 4800 \\
\hline Nanjing University & 4600 \\
\hline Beijing University of Science & 5000 for Arts, 6000 for Science \\
\hline Beijing Foreign Trade University & 6000 \\
\hline Shanghai Foreign Languages University & 10000 \\
\hline Fudan University & 5500 \\
\hline Harbin University of Industry & $4000-5500$ \\
\hline Nankai University & $4200-5500$ \\
\hline Zhongshan University & 4560 for Arts, 5160 for Science \\
\hline Sichuan University & 4600 for Arts, 5000 for Science \\
\hline Xi'an Jiaotong University & $3750-5200$ \\
\hline Zhejiang University & 4800 \\
\hline
\end{tabular}

This increase greatly contributed to the amelioration of the financial situation for Chinese universities. For example, Huazhong University of Science and Technology had experienced an income increase from 0.4 billion in 1998 to 1.4 billion Yuan in 2003, according to Ouyang Kang (2004), Assistant President of that key university in China.

The educational enterprise in China has been funded in a multiplicity of ways since 1949. The central authorities have always had the most to say about collection and allocation of funds for both formal and non-formal schooling. The Chinese educational system remains highly centralized even today. However, with the introduction and especially the dramatic increase of tuition fees, Chinese universities are becoming topics of increasingly hot debates among people from all walks of life.

\section{Privatization In China's Higher Education: Pros And Cons}

A basic assumption underlying privatization is that students and their parents who pay the hefty tuition and other fees have more power to monitor education services. "They will make sure that the education is of satisfactory standard... Privatization can include giving parents more choice over what goes on in schools, or what types of school are available, even where all these choices are within the public sector" (Belfield \& Levin, 2002, p.22). However, this does not seem to apply to the situation in China, at least not for now. Chinese education is still very centralized, and all implementation processes of education policies 
are top down, initialized by the MOE. When we scrutinize Belfield and Levin's evaluative criteria: freedom of choice, efficiency, equity, and social cohesion, we often see the opposite of what privatization is claimed to be. The prestigious universities are still the public universities, and they have the power to decide how much tuition fee they want to charge (although officially MOE is still in control of setting the price tag), and they are more willing to take in the students who can afford to pay the staggering tuition and other fees. Instead of becoming a source of social cohesion, the current education reform practice has virtually broken the social climbing system formerly affordable to most members of the society. The social ladder has become corrupted so that the impoverished will have an even slimmer chance to be promoted to a better position. This situation is exacerbated when you think of the 80 per cent of the 1.3 billion Chinese people who are impoverished according to any standard.

It is a fact that privatization has become a salient feature in the past decade or two in China's post secondary education. One major purpose of China's private higher education expansion is to supplement the inadequate public sector and state finance. Thus China epitomizes the international tendency to look on private higher education as a way to meet otherwise contradictory enrolment and financial objectives. With this highly instrumental approach, privatization brings with it highly controversial ideas among researchers and people from all walks of life. After all, China's private higher education appears to have very little effect on diversity and equity of the system, and it incurs unquestionably disparities among different social groups. Polarization seems to be a better word to describe the consequence of this education reform.

For some, the tuition reform breaks up the old, mono-funding structure in Chinese higher education, and provides a funding channel for universities and colleges, which will financially invigorate the development of Chinese higher education ( $\mathrm{Li}, 1996)$. The privatization process is deemed to have provided more venues to diversify the funding, curriculum, and administration structures of Chinese tertiary system and is a positive step toward modernization. As a result of privatization, more students are able to pursue their higher education. According to the official Xinhua News Agency, in 20058.67 million students registered for the postsecondary entrance examination and around 4.75 million were admitted into the system, making China the world's largest provider of higher education (Xinhua News Agency, 2005).

Ouyang (2004) sums up the significant changes happening to the Chinese postsecondary education. Teaching facilities and equipment in higher education have undergone considerable reconstruction. More student dorms, dining halls, teaching buildings, laboratories, and computers have now found their way onto university campuses. Curriculum materials are able to be updated. Pedagogical reforms are also available as a result of the competitions between various private educational institutions.

For others, however, the so-called diversification means nothing but more pressure on the already stringent family financial situations. When the tuition fee increase was initiated in 1989, students were charged 200 Yuan every year. 
According to Statistics China, the annual income for city residents in that year was 1376 Yuan, so the tuition fee was one seventh of the annual income. In 2001 , tuition fees soared to 5000 to 10000 Yuan, a 25 to 50 fold increase. City resident average income, however, was 6860 Yuan, an increase of about four times, or 2.3 times actual increase after deduction for inflation. The increase of tuition fees is ten times faster than the average increase of a city resident annual income. This has caused serious social problems for some disadvantaged families, especially those farmers in the rural and remote areas, and those workers who have been just laid off as a result of the nationwide economic reform.

High tuition and costly school expenses block children of poor families from entering colleges and increase the family's debt. Chinese people value family, and parents consider it their duty to take care of their children's education expense. There are some reports that some parents even committed suicide due to their inability to pay for their children's school expenses. Examples abound such as Mr Zheng in Baoji City, Shaanxi Province, who jumped from a seventh floor in 2002 because his son's admission cost for Fudan University was 7000 Yuan and he had no means to amass this staggering sum of money. Chen Nenggen from Aimin Village Dongbing town, Lishui County, Jiangsu Province committed suicide by drinking a whole bottle of pesticide on August 6, 2003 because he could not collect his daughter's tuition for college. Another farmer from Yulin City, Shaanxi Province committed suicide on July 14,2004 . His daughter, Jing Yanmei, was a top honor student and was admitted to a university; however financial hardship precluded her father from raising tuition money. He then hanged himself out of sheer hopelessness ( $\mathrm{Li}, 2004)$. Although these are only anecdotal events, many disappointed parents are questioning whether the reform is creating social and education progress when many impoverished families are unable to send their children to school. Wu (2004) identifies three major problems in the current higher education privatization in China:

First of all, it stagnates the national economy. One of the original rationales for tuition fee increase was to mobilize consumption and contribute to the development of the national economy. Today's situation with many families has proved otherwise. Tuition fees and other education costs have taken the lion's share out of even the affluent city residents' family income; so that everyone has to save money from even before a child is born in order to pay the hefty costs for their child's education.

Secondly, it suffocates the upward mobility for the majority of the impoverished population. Over 2000 years ago, Confucius advocated that "education should be provided without regard to class." He further clarified that "I will extend teaching to any one who pays a bundle of preserved beef (as a symbolic tuition fee)". This implied an unprecedented extension of right to education from the few ruling nobles to the broad masses (Zhou, 1995, p.84). From the Song Dynasty, China's civil service examination system provided candidates for official positions by special examinations (Wolfgang, 1960). 
"Beginning with the Sung period the examinations became the major road to power and wealth, contrary to the old practice whereby a strong economic position had entitled one to special political privileges" (p.7). Until the abolition of the civil service examination system in 1905, power and wealth could be achieved by participation in these competitive examinations, which provided the main road of upward mobility. This caused an extraordinary appreciation of book learning throughout ancient China (Jurgen, 1984). Even before the 1980s when tuition fees were initiated, many young people were able to change their social and economic status by passing the national entrance examination held annually. The current ongoing privatization and especially the soaring of tuition fees scaffold the upward mobility of social ladder for many disadvantaged families. It is reported that students from the impoverished agricultural families used to take around 60-70 per cent of the student population before the tuition fee reform, proportionate to the ratio of farmers in the whole country. Today however, only 30 per cent of the student population come from the rural areas (Wu, 2004).

Thirdly, the soaring increase in student enrollment leads to potential widespread unemployment for the many disadvantaged university graduates. Because of the increased enrollment, more students are able to pursue their post secondary education. However, since the increase is too drastic and far exceeds the development speed of economy and industry, more students are doomed to be unemployed after graduation. In a society where social connections mean a lot to many people, the dreams of many students from disadvantaged families to find a good job after graduation may turn out to be a wild goose chase, after they managed to pay the hefty tuition fees for four years.

\section{Suggestions And Policy Implications}

As can be seen from the above comparison and analysis, privatization in China takes a quite distinct touch in recent years; it can be called privatization Chinese style or privatization "with Chinese characteristics", as the government calls it. When the world's most populous and disadvantaged people in the less developed areas in China are treated like cash cows, no wonder articles like "Tuition fee: How many more people do you want to kill", "Education reform: The death knell calling for you", and "When can the tuition-fee-kills tragedies phase out" keep appearing in the media (See for example, www. bbsland.com). Opinions regarding the tuition fee reform are receiving more and more polar ideas from the mass and the education authorities. The following are some of my reflections regarding privatization and the tuition fee reform in particular.

First of all, cost sharing is not a panacea for China's problem in increasing student enrollment and lowering government investment. Even Johnstone himself has realized that cost sharing, to be compatible with access and equality, must be accompanied by policies and programs of financial assistance, other programs to compensate for unequal educational opportunities at the secondary level, and reforms in both curriculum and pedagogy (Johnstone, 2004, p.11). He also cautioned that cost sharing may be better viewed as a concept and a general 
policy direction than a specific prescription of agenda. To prevent the situation from deteriorating in China's post secondary education, and to prevent potential social turmoil, a tuition fee freeze policy should be implemented as soon as possible.

Secondly, more resources must be allocated toward the assistance of the students from impoverished families. Government investment must be strengthened. During the decades from 1991 to 2001, the education expenditure relative to Gross Domestic Production (GDP) in China increased less than 1 percent (see Table 2). This is unacceptable when the national economy is increasing at a speed of 7-9 per cent annually. New forms of student loans and means-tested grants are only being developed, as reported by Shen and $\mathrm{Li}$ (2003). More venues should be provided in order to alleviate some of the wretched living conditions of students from low income families. Although it is reported that more Canadian students are relying on Food Banks to survive their university life, because of the tuition fee hike (Galbraith, 2004), the Chinese university students from impoverished families can only look at this with admiration and starvation.

Table 2: Education Expenditure Relative to GDP (1991-2001) (Unit:\%)

\begin{tabular}{l|lllll}
\hline 1991 & 1993 & 1995 & 1997 & 1999 & 2001 \\
\hline 2.85 & 2.51 & 2.46 & 2.55 & 2.83 & 3.19 \\
\hline
\end{tabular}

Source: National Statistics Bureau, China Statistics Yearbook, 1991-2001

Thirdly, according to the Decentralization Thematic Team (2006), the most complete forms of decentralization from a government's perspective are privatization and deregulation. The situation in China seems to suggest that this decentralization is still highly centralized, allowing privatization to a degree but very little progress in deregulation. This tendency should be withheld so that universities have more say in their own development, public and private as well. Universities should have more right in their curriculum and pedagogical reforms and take more responsibility and accountability for the fees they have charged. Students and their parents (the so-called education consumers) should be given more say in their choice of services they need and the kind of education they need. Only when universities and educational administrators are held accountable can marketization and privatization in the economy as well as in education lead to increased competition and exchange, improved efficiency and effectiveness and increased output.

To conclude, privatization and marketization seem to have become a trend in today's globalized world, for good or for bad. A significant influence from this trend is the privatization and increase of tuition fees in China's higher education system. However, when Mammon has become dominant for policy makers, a still highly centralized Chinese education system can yield detrimental 
results for the people and the country's future at large. When the most impoverished members of the society can not get significant support from the post secondary education system and the society becomes more polarized, something has definitely gone wrong.

\section{References}

Belfield, C.R. \& Levin, H.M. (2002). Education Privatization: Causes, Consequences, and Planning Implications. Paris, UNESCO: International Institute for Educational Planning.

Caillods, F. (2002). Preface. In C.R. Belfield \& H.M. Levin (Eds.) Education Privatization: Causes, Consequences, and Planning implications. UNESCO: International Institute for Educational Planning.

Chen, Y. et al. (1981). Zhongguo Gudai de Shuyuan Zhidu (China's Ancient System of Private Academies). Shanghai, China: Shanghai Education Press.

Cheng, K. (1995). Education Decentralization and the Market. In L. Wong \& S. MacPherson (Eds.) Social Change and Social Policy in Contemporary China. Aldershot: Averbury.

China National Institute for Educational Science Research (1995). A Study of HGOSponsored and Private Higher Education in China (Beijing, sponsored by UNESCO).

Decentralization Thematic Team (2006). Issues in Program Design: Participation and Decentralization. A Columbia University project sponsored by World Bank. Retrieved January 26, 2005, from www.ciesin.columbia.edu/decentralization/English/Issues/Participation.html

Ding, G. \& Liu, Q. (1992). Shuyuan Yu Zhongguo Wenhua (Private Academics and Chinese Culture). Shanghai, China: Shanghai Education Press.

Galbraith, K. (2004). Canadian Students Increasingly Rely on Food Banks. The Chronicle, 50 (18), A 38.

Hayhoe, R. (1984). The Evolution of Modern Chinese Educational Institutions. In R. Hayhoe (Ed.) Contemporary Chinese education, (pp. 26-46). Sydney, Australia: Croom Helm Australia Pty Ltd.

Hayhoe, R. (1996). China's Universities, 1985-1995: A Century of Cultural Conflict. New York: Garlard Publishing Inc.

Johnstone, D. B. (2004). The Economics and Politics of Cost Sharing in Higher Education: Comparative Perspectives. Economics of Education Review, 23(4), 403-410.

Ilnyckyj, R. (2003). Tuition around the world. [Electronic version]. Gauntlet News, December 4.

Levin, H.M. (2001). Privatizing education: Can the market deliver freedom of choice, productive efficiency, equity and social cohesion? Boulder, CO: Westview Press.

$\mathrm{Li}, \mathrm{T}$. (2004). Chen Zhili under fire for "commercialization of education". Epoch Times (Translated from the Chinese version).

Li, X. (1996). Tuition reform in Chinese higher education. Canadian and International Education, 25 (1), 87-99.

Ling, B. (1993). Tuition reform for higher education. Beijing Review, 36 (29), 18-19. 
Min, W. (1994). People Republic of China: Autonomy and accountability. In G. Neave \& F. Van Vught (Eds.) Government and higher education relationships across three continents. Oxford: Pergamon.

Mohrman, K. (2003). Higher education reform in mainland Chinese universities: An American's perspective. Resources from Hong Kong-America Center. Retrieved September 6, 2004, from:

http:/www.cuhk.hk/hkac/thematic/innovation/resource/prc/kat_art/p08.htm.

Mok, K.H. (1996). Marketization and decentralization: Development of education and paradigm shift in social policy. Hong Kong Public Administration, 5 (1), 35-56.

Ouyang, K. (2004). Higher education reform in China today. Policy futures in education, 2 (1), 141-149.

Shen, H. \& Li, W. (2003). A review of the student loan scheme in China. Final report prepared for the UNESCO-Bangkok Regional Study on Student Loan Schemes.

Shi, Q. et al. (2004). Affiliated colleges and private higher education development in China-Take independent college as an example. Paper presented to Forum 2004 hosted by OCAIR (Overseas Chinese Association for Institutional Research).

Wolfgang, F. (1960). The reform and abolition of the traditional Chinese examination system. Cambridge, Mass: Harvard University Press.

Wu, H. (2004). Xuefei Bao Zhang de San Da Houguo (Three Major Consequences from the Tuition Fee Hike). Retrieved and translated, May 4, 2005, from: http:/www.bbsland.com/article Reader.Php?idx=81015.

Wuhan University (2003). Wuhan Daxue Chouzi Banxue Guanli Banfa (Shixing) [Wuhan University Regulation for the Administration of Educational Donations]. Wuhan University Research Institute of International Law.

Xinhua News Agency (2004). Jumping development in Chinese education. Retrieved and translated August 24, 2004, from:

http:/wwwl,people.com.cn/GB/jaoyu/1053/2735769.html.

Xinhua News Agency (2005). Report on 2005 China's postsecondary entrance examination. Retrieved and translated on October 2, 2005, from: http:/www.xhby.net/xhby/content/2006-01/24/content_1123689.htm .

Yang, B. \& Peng, D. (1992). Zhongguo Shuyan Yu Chuantong Wenhua (Chinese private academies and traditional culture). Changsha, China: Hunan Education Press.

Yang, D. (1996). Perspectives on non-governmental schools in China. Paper presented at the Shanghai International House for Education, 15-20 August, Shanghai.

Zhou, Y. (1995). Tuition: Public to invest more capital in education. Beijing Review, 38 (39), 15-17. 